\title{
Critical Success Factors of Knowledge on Sustainability in Malaysian Higher Education.
}

\author{
${ }^{1}$ Aini Arifah binti Abdul Karim, ${ }^{2}$ Sabrina Abdullah*, ${ }^{3}$ Ahmad Fauzi Mohd Ayub, ${ }^{4}$ Amir \\ Hamzah Sharaai \\ ${ }^{1,2,4,5}$ Faculty of Forestry and Environment, UPM \\ ${ }^{3}$ Faculty of Educational Studies, UPM \\ ainiarifah@gmail.com ${ }^{1}$, yuekming@upm.edu.my ${ }^{2}, \underline{\text { afmy@upm.edu.my }}{ }^{3}$, amirsharaai@upm.edu.my $^{4}$
}

Article History: Received: 11 January 2021; Accepted: 27 February 2021; Published online: 5 April 2021

\begin{abstract}
This study aims to investigate Malaysia's Institutes of Teacher Education (ITE) students' knowledge on sustainability toward environmentallysustainable behaviour (ESB). The model adapted is based on Hines, Hungerford and Tomera's Environmental Responsible Behaviour Model which was established since 1987.The nature of this study was descriptive, and the data were collected using cross-sectional survey. A total of 425 participants responded to a questionnaire developed for this study. Several procedure was carried out in order to assess the validity and reliability of the questionnaire using PLS-SEM.The study revealed that the Malaysian Higher Education students showed a high level of knowledge of sustainability action skills, knowledge of sustainability strategies and knowledge of sustainability issues toward ESB and the environment. Findings associated with students' gender, age, ethnicity, field of study and academic program were also reported and discussed.First, the participating students came from Institutions of Teacher Education. Although this institution is a major teacher training centre in the nation, further studies should include samples from other public and private institutions. Second, this study did not examine the correlation among the three main components: knowledge of sustainability action skills, knowledge of sustainability strategies and knowledge of sustainability issues.Limited studies have been conducted in Malaysia on ITE although the institutionsare supporting ESD through the Sustainable ITE program. Therefore, this study is exploring the critical success factors of knowledge on sustainability action skills, knowledge on sustainability strategies and knowledge on sustainability issues on environmentally sustainable behaviour ofteacher candidate students in Malaysia. In addition, past studies have recommended to investigate and look into the environmentally sustainablebehaviour among the younger generations, especially those with higher education levels, especially because inevitably, they are agents of change, and also they will be affected by the environmental issues that are caused by the current human activities.

This paper also providesvaluable insights that foster a much better understanding in regards to the role of Institutions of Teacher Education (ITE) in assisting sustainable development, addressingthe important key issues to be considered in education system.
\end{abstract}

Keywords: sustainability in higher education, ESD, environmentally sustainable behaviour, PLS-SEM, Environmental Responsible Behaviour Model (ERB).

\section{Introduction}

Since environmental citizenship among the citizens of Malaysia is lacking (Ho, Kamaruddin, \& Ismail, 2016), thus, it is inevitable that the implicit role of the teachers who are also known as environmental citizenship role model to acquire desirable characteristics. Since its introduction through the Bruntland Report entitled 'Our Common Future ' at the United Nations Conference on Environment and Development in 1987, the notion of ' sustainable development' has received worldwide attention. Institutions of Teacher Education has initiated a few method towards making this a goal a reality. As recommended by Leal Filho (2015), much stronger involvement in the community of higher education initiates a chain reaction which can enhance the provision of ESD whether the settings are in formal or non-formal.Like other nations, Malaysia has collectively endorsed and committed to sustainable development initiatives. In line with the recommendations by the authorities to promote sustainability in higher education, a program was introduced to all Institutes of Teacher Education (ITE) in Malaysia to increase the environmentally sustainable behaviour among the teacher trainees in the institutions was introduced in 2012. This is not an additional program that will burden the institute as the planned activities are actually in the long-term curriculum, co-curriculum, management and environmental program. This program is known as Sustainable ITE or "IPG Lestari" which is a collaborative network between Institutes of Teacher Education and WWF (World Wide Fund for Nature), Universiti Pendidikan Sultan Idris (UPSI), University Sains Malaysia (USM) and Natural Resources and Environment Board Sarawak (NREB). The aim of Sustainable ITE is to make sustainability in decision-making and action a culture among future teachers and local communities through increased knowledge, instilling awareness and practicing sustainable lifestyles. It illustrates the commitment and support of Malaysian Ministry of Education Institutes of Teacher Education (IPGM KPM), towards making Sustainable ITE as a brand that is advocated, practised and adopted by all the 27 campuses 
throughout the country. The programme adopts its concept from Eco-Schools programme and it aspires to empower preservice teachers to take action to find solutions to environmental issue in their campus area.

As iterated by Owens \& Legere, 2015, the work in regards to sustainability education is only the beginning. In the implementation of the Education for Sustainable Development (ESD) several research in higher education institutions and in universities, have been carried out on how the implementation of the ESD promoted the purpose of the Sustainable Development Policy (Scoullos, Malotidi, Lindroos, \& Suomalainen, 2017; SingerBrodowski, 2017; Torres, Vieira, Rodrigues, Sá, \& Moreira, 2017). In terms of effectiveness and assessment, ESD implementation has provided different kinds of results. Although UNESCO has indicated that ESD is not a specific program with specific content intended for any individual or organization. Rather, it is "a framework for many forms of education that already exist and new ones that remain to be created" It is intended as life-long learning that enables people of any age to acquire the knowledge and values necessary to make a significant contribution to the building of a sustainable future. UNESCO (2014) advises the inclusion of ESD education and learning in crucial sustainable development issues, such as "climate change, disaster risk reduction, sustainable livelihoods, sustainable consumption and growth, biodiversity and the reduction of poverty" (UNESCO, Buckler, \& Creech, 2014)

Before reviewing relevant literature, the key terms used in this document is briefly described here. Proenvironmental behaviour is "a practice that deliberately seeks to minimize the negative effect of its actions on the natural world" (Kaiser, F.G., Woelfing, S. \& Fuhrer, 1999)and also known as sustainable behaviour (Clayton \& Myers, 2009)and environmentally responsible behaviour (Kollmuss \& Agyeman, 2002). Measures of such activities include the use of renewable fuels (e.g. solar and wind) rather than fossil fuels for industrial purposes, proper management and reuse of waste, conservation of energy and water, etc.

Previous researches across the globe studying on the behaviour of the educational citizens towards the environment have revealed various significant results(Filho et al., 2017).In the local context, a model constructed by Mahat \& Idrus (2016)called the ESD model indicated that the Sustainable School Program implemented in Malaysia is a significant indicator for the achievement of sustainable school. Later in 2018, a qualitative study in Vietnam interviewing secondary teachers and educational stakeholders disclosed that qualification and socialization, are a huge concern in which revealed the importance of education in the role of sustainable development(Nguyen, 2018). Since Vietnam is another developing country like Malaysia, this finding is rather important, as it could be the same thing for Malaysia in terms of depending on the importance of education to further enhance the role of sustainability. Another study byKidman, G., Chang, C-H., \& Wi, 2018 concluded that with greater knowledge about the environment especially on climate change issue, people can make informed decisions and be more motivated to act with pro-environmental behaviour. This is in line with the reason why pre-service teachers for the primary schools are selected for this study. It gives the more reason as to tackle the issues of sustainability from a very young age because these young generations will be the ones making informed and wise decisions in the future.

Based on previous literature review, this paper seeks to address the following research questions:

i. What is the critical success factor for knowledge of sustainability action skills variable among pre-service teachers in Malaysia?

ii. What is the critical success factor for knowledge of sustainability strategies variable among pre-service teachers in Malaysia?

iii. What is the critical success factor for knowledge of sustainability issues variable among pre-service teachers in Malayia?

By responding to the questions of this study, it can provide an overview of the knowledge on sustainability among pre-service teachers. Knowledge of sustainability are not only vital among those who are studying in the faculty of built environment, or architecture, biology or even engineering. Those who are majoring in teaching and education, also known as the pre-service teachers are the ones who will be part of our children's phase of growing up. It is important for these future teachers to have the knowledge to become someone with environment sustainability behaviour (Birdsall, 2014). The children need to know from their very young age and one way of instilling knowledge to our young children is by making sure their teachers have this knowledge too. The findings of this research bring in new teacher education approaches to narrow the gaps in knowledge and behaviour in order to promote sustainability behaviour and endorse teachers as social agents of change.

Among the past studies that had quite a major impact on this issue is a study done by Gericke, Boeve-de Pauw, Berglund, \& Olsson (2018) which elaborated on the implementation of Education for Sustainable Development (ESD) in Swedish schools among $2,4136^{\text {th }}, 9^{\text {th }}$ and $12^{\text {th }}$ grade students and the results revealed that the implementation of ESD in the Swedish schools wasn't particularly successful since only a small positive effects of an ESD approach among $6^{\text {th }}$ grade and even a smaller negative effect of an explicit ESD approach among the $9^{\text {th }}$ grade.

Another study done by Kalsoom \& Khanam (2017) on sustainability consciousness among Pakistani pre-service teachers established results that indicate respondents' knowledge, attitude and behaviour regarding sustainability were not same. This finding is not indicating that the respondents had knowledge of sustainability issues 
although lacking in sustainability attitudes and behaviours. However, it indicates that the Pakistani pre-service teachers had relatively more knowledge about sustainability issues compared to the level of their own attitudes and their behaviours towards sustainability.

In 2014, a study on Turkish pre-service teachers compared difference between those who enrolled for Environmental Education courses and those who did not. The population of the research is consisted of first and third year students with approximately 272 student teachers. The results of the research revealed that students who enrolled for environmental education related to the basic concepts of the environment are practically more successful than the first year students did not take any course about the environment yet. Nevertheless, the attitude of the pre-service teachers in relation to the environment displayed differences of the gender but it is a general agreement that these differences disappear once environmental education is obtained(Alim M, 2014). This study is crucial because it establishes the knowledge variable, a variable that is measured in this particular study. The importance of having knowledge in environmental sustainability is discussed throughout this paper.

In addition, a study by Meyer in 2015 provided evidence that education causes individuals to be even more concerned and behave in a more environmentally friendly manner. This is a very strong evidence as it proves how important educating the pre-service teachers prior to becoming real teachers with the correct behaviour towards the environment.

\section{Theoretical foundation}

As a foundation for this study, the conceptual framework was based on Hines, Hungerford, \& Tomera's(1987) Model of Environmental Responsible Behaviour. According to this model, there are six variables that explains an environmentally responsible behaviour of an individual. They are: Knowledge of issues: Individuals has to be familiar with the environmental issues surrounding them as well as its causes.

Knowledge of action strategies: The individual has to know the action needs to be taken in order to lower the impact on the environmental issues.

Locus of control: How a person's perception of their ability to make changes through his or her own behaviour. An individual who has a strong internal locus of control really believe that the action that they take can make changes. On the other hand, individual with an external locus of control, feel that their actions are insignificant, and feel that change can only be done by others who are more powerful.

Attitudes: Individuals with high pro-environmental attitudes were more likely to engage in pro-environmental behaviour, although the relationship between attitudes and behaviour still proved to be low.

Verbal commitment: This basically means the communicated willingness in taking some action and also giving some indication about an individual's willingness to be engaged in pro- environmental behaviour. Individual sense of responsibility: Individual who has a bigger sense of responsibility and are likely to engage in environmentally responsible behaviour(ERB).It seemed that this framework is even more sophisticated than the one introduced by Ajzen(1985)but still the identified factors in this framework are insufficient in explaining proenvironmental behaviour. It is inevitable that there are many more factors which can influence proenvironmental behaviour. Hines et al. (1986-87) named these as 'situational factors' which can include social pressures, economic constraints, as well as opportunities to select different actions. However for this particular study, the researcher is only focusing on the effect of knowledge (knowledge of issue and knowledge of action strategies) and situational factors (in this study, the situational factor is interpreted as the activity involvement) to be the key determinants of the predictive model.

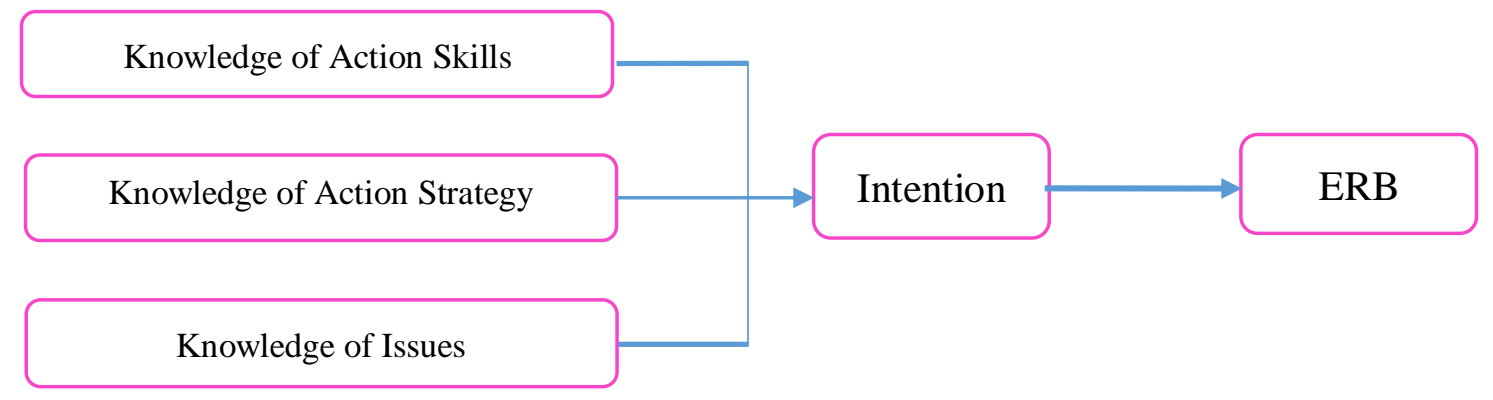

Figure 1. Conceptual framework adapted from Hines, Hungerford and Tomera (1987)

The overall aim of this paper is to investigate the effects of the implementation of ESD in the Institute of Teacher Education (ITE), Malaysia. The investigation was pursued using quantitative cross-sectional research design. A total of five campuses of ITE were involved in this study. Students in the institutes which is also known as the pre-service teachers were selected randomly. The total number of sample needed to respond to the questionnaire were determined by using Cochran's (1977) formula.

Population, Sample Size and Sampling Procedure 
This research was conducted among pre-service teachers who are still in the training and there are at least 2 programmes and 5 different levels of training. The sample size was calculated using the Cochrane's formula where only 358 teachers were needed as respondents. Simple random sampling methods were utilized and the samples were divided as to produce equal proportion of each ITE in the sample in order to be as close to the target population as possible (Salkind, 2010). In order to determine the number of samples of this study, researcher have used the sample size formula by Cochran (1977). The sample computation formula (Cochran, 1977) for continuous data is as follows:

$$
\begin{aligned}
& n=\frac{n^{\circ}}{1+\frac{n^{\circ}}{N}} \\
& \text { variable; } \quad n=\quad \text { sample size } \\
& n=\quad \mathrm{t}^{2} \mathrm{~s}^{2}
\end{aligned}
$$

Replace values into the formula:

$$
\begin{gathered}
n \quad=\quad(1.96)^{2}(1.25)^{2} \\
=\quad(3.84)(1.56) \quad(0.15)^{2} \frac{(3.84)(1.56)}{(0.15)^{2}} \frac{(3.84)(1.56)}{(0.15)^{2}} \\
=\quad 260 \\
t \quad=\text { value for selected alpha level of } 0.05(0.025 \text { in each tail })
\end{gathered}
$$

( $\mathrm{t}$-value for alpha level of .05 is 1.96 for sample size above 120

$\mathrm{s} \quad=1.25$ (estimate of variance for a 5 -point scale calculated by using 5 divided by 4 )

$d \quad=0.15$ (acceptable margin of error for mean being estimated (Bartlett, Kotrlik \& Higgins, 2001) acceptable margin of error $=.03 \times 5$ (points on scale)

$$
\begin{gathered}
\text { Therefore, } \mathrm{n}=\frac{\text { Research population }(\mathrm{N})=\frac{260}{1+260 / 340}}{} \\
=\quad 260 \text { persons }
\end{gathered}
$$

The number of respondents from each ITE were then calculated as to find the proportional number to suit the total population from each institutions. Salkind (1997) in Bartlett, Kotrlik,\& Higgins (2001) recommended to do oversampling if the questionnaires are being mailed to the respondents. Salkind recommended an additional 40$50 \%$ to account for cases like uncooperative respondents. Therefore, the sample size determined has taken into an additional account $50 \%$ of number of respondents which makes the sample size is 415 . Intact class units were then selected from within sub-populations and from different subject options. Sampling units were chosen based on availability of the class units for administration of the questionnaire during the appointed day and time.

\section{Instrumentation}

For this study, a questionnaire was distributed to 358 student teachers from 5 ITE of 5 different zones in Malaysia. The questionnaire was adapted from various previous studies. Among the past studies that have been selected to adapt the questionnaire are the Sustainability Consciousness Questionnaire which was developed by Olsson (2014) and Al-Naqbi \& Alshannag (2018) to measure the knowledge of sustainability among these preservice teachers. A back to back translation was done to the questionnaire to further adapt the questionnaire to the Malaysian context. The survey was then structured to be more suitable for the studentteachers' age range, where some policy jargons were not used in some of the items. To further strengthen the face validity of the questionnaire design, the expertise of a group of validators which were selected amonglecturers and educators from the ITE, university and school were used to assist in confirming the suitability of every items in the questionnaire. A few items were added and deleted to the knowledge constructs to ensure that the items were enough to measure the dimensions. 
Data Analysis

The data obtained from the questionnaire were processed at the basic level using the IBM SPSS software. Descriptive statistical analysis was used to obtain mean values, mode and standard deviations. In terms of analysing the measurement model to assess the internal consistency, convergent validity and discriminant validity, researchers applied SmartPLS 3.0 software as to calculate the AVE, composite reliability and crossloadings(Hair et al., 2015).

Validity and Reliability of the instrument

Fraenkel and Wallen (2013) defined validity as the resolution of substantive truth and usability of an instrument that essentially permits it to be determined by means of the collected data. The reliability of an instrument is when the instrument can measure what it was intended to measure (Ghazali and Sufean, 2018). Based on Fornell and Larcker (1981), convergence validity means when all the three conditions are met, which are; cross loading values exceeding 0.7, composite reliability values not less than 0.8 and AVE values exceeding 0.5. Since the results indicate that all these requirements have been met, this instrument has the requisite convergence validity.

Table 1. Cross loadings, composite realibility \& AVE value of each item

\begin{tabular}{|c|c|c|c|c|}
\hline Variables & Item & Cross loading & $\begin{array}{l}\text { Composite } \\
\text { Reliability }\end{array}$ & AVE value \\
\hline \multirow{5}{*}{$\begin{array}{l}\text { Knowledge } \\
\text { Action } \\
(\text { KAS })\end{array}$} & KAS 1 & 0.590 & \multirow[t]{5}{*}{0.837} & \multirow[t]{5}{*}{0.509} \\
\hline & KAS 2 & 0.737 & & \\
\hline & KAS 3 & 0.815 & & \\
\hline & KAS 4 & 0.700 & & \\
\hline & KAS 5 & 0.705 & & \\
\hline \multirow{5}{*}{$\begin{array}{l}\text { Knowledge } \\
\text { Sustainability } \\
\text { Strategies } \\
\text { (KSS) }\end{array}$} & KSS6 & 0.704 & \multirow[t]{5}{*}{0.859} & \multirow[t]{5}{*}{0.522} \\
\hline & KSS7 & 0.817 & & \\
\hline & KSS8 & 0.813 & & \\
\hline & KSS9 & 0.741 & & \\
\hline & KSS10 & 0.621 & & \\
\hline \multirow{5}{*}{$\begin{array}{l}\text { Knowledge } \\
\text { Sustainability } \\
\text { Issues } \\
\text { (KSI) }\end{array}$} & KSI11 & 0.781 & \multirow[t]{5}{*}{0.841} & \multirow[t]{5}{*}{0.515} \\
\hline & KSI12 & 0.798 & & \\
\hline & KSI13 & 0.655 & & \\
\hline & KSI14 & 0.653 & & \\
\hline & KSI15 & 0.688 & & \\
\hline \multirow{7}{*}{$\begin{array}{l}\text { Behavioural } \\
\text { Intention } \\
\text { (IB) }\end{array}$} & IB16 & 0.710 & \multirow[t]{7}{*}{0.876} & \multirow[t]{7}{*}{0.503} \\
\hline & IB17 & 0.706 & & \\
\hline & IB18 & 0.764 & & \\
\hline & IB19 & 0.714 & & \\
\hline & IB20 & 0.736 & & \\
\hline & IB21 & 0.621 & & \\
\hline & IB22 & 0.706 & & \\
\hline \multirow{5}{*}{$\begin{array}{l}\text { Environmental } \\
\text { Sustainability } \\
\text { Behaviour } \\
\text { (ESB) }\end{array}$} & ESB23 & 0.731 & \multirow[t]{5}{*}{0.844} & \multirow[t]{5}{*}{0.520} \\
\hline & ESB24 & 0.695 & & \\
\hline & ESB25 & 0.716 & & \\
\hline & ESB26 & 0.691 & & \\
\hline & ESB27 & 0.769 & & \\
\hline
\end{tabular}




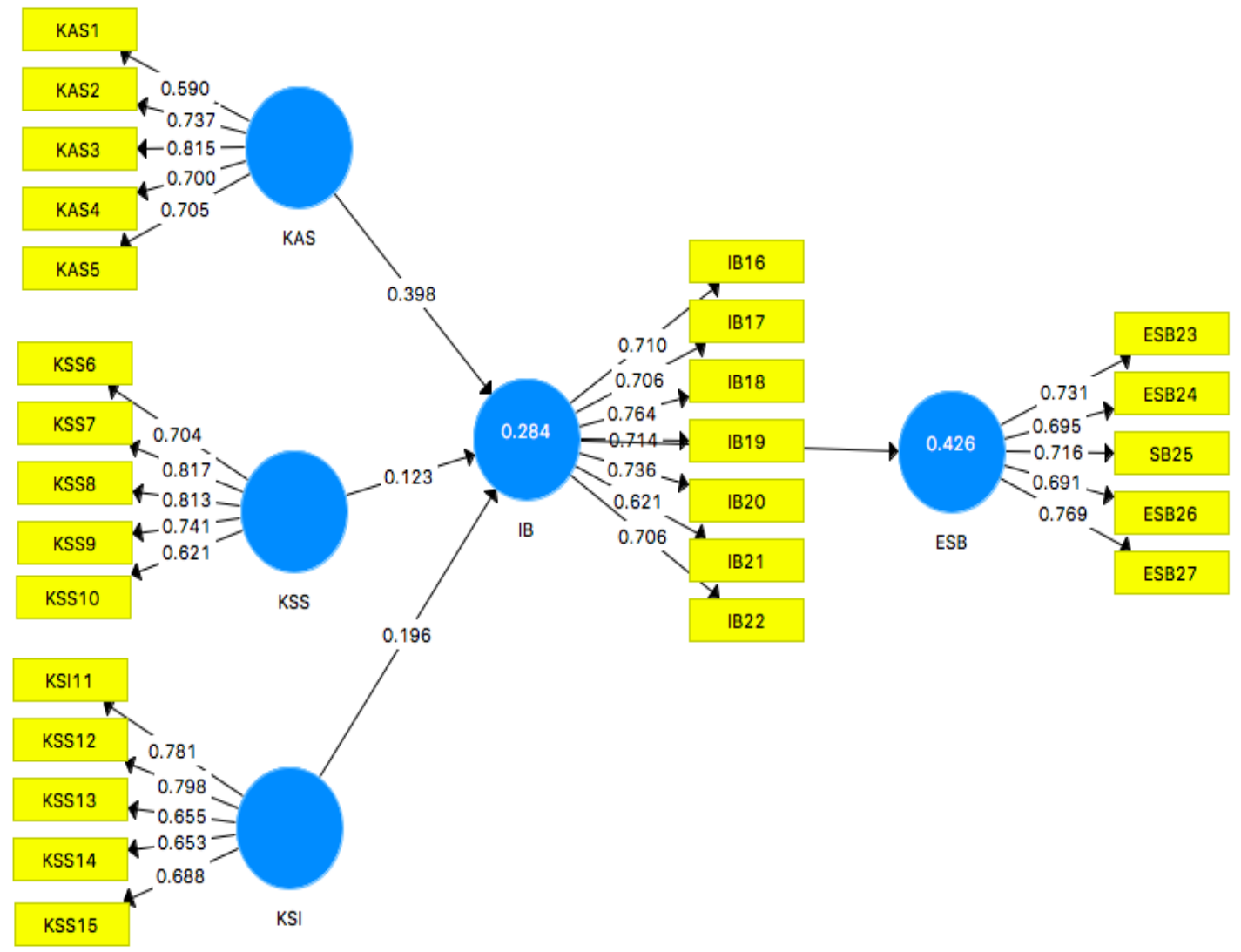

Figure 2.Analysis of the measurement model.

Kerlinger (1973) indicates that reliability is an instrument's degree of conformity and trust with a secure, consistent, cordial and reliable character. Researchers must test the reliability of the instrument, as the alpha coefficient is very important for testing and analysis of the variables (Reber, 1985). Therefore, the value of the alpha was obtained using SPSS, and the values were interpreted based on the strength of association demonstrated by Hair, Babin, Money and Samouel (2003) as illustrated in Table 2.Based on the results, the Cronbach's Alpha value of all constructs are greater than 0.700 . Thus, indicating good reliability of the instrument.

Table 2.The value of Cronbach's Alpha coefficient by constructs

\section{Construct}

Knowledge of Sustainability Action Skills (KAS)

Knowledge of Sustainability Strategies (KSS)

Knowledge of Sustainability Issues (KSI)

Behavioural Intentions (IB)

Environmental Sustainability Behaviour (ESB)

\section{Cronbach's Alpha coefficients}

0.757

0.795

0.765

0.835

0.769

\section{Results}

Demographics

Altogether, there were 358 respondents comprising of $76.7 \%$ of female respondents and $23.3 \%$ male respondents. Respondents were predominantly of Malay ethnicity with $61.7 \%$ of the total population, followed by Chinese with $27.5 \%$, Indian 5.3\%, Malay Bumiputra 5.1\% and Natives $0.5 \%$. All the respondents are in the age range of 17-23 years old. It is also important to note that $33.2 \%$ of the total population are studying language (Malay, English, Chinese and Tamil), 33.4\% are from the social studies stream (Islamic studies, music, counselling, history and early childhood education) and $33.4 \%$ are majoring in science stream (mathematics and science). 
Table 3.Demographic profile of student teachers

\begin{tabular}{|c|c|c|c|}
\hline & Profile & $\begin{array}{l}\text { Frequency } \\
(\mathrm{N}=415)\end{array}$ & Percentage (\%) \\
\hline \multirow{5}{*}{$\begin{array}{l}\text { Insitutes of } \\
\text { Teacher } \\
\text { Education } \\
\text { (ITE) }\end{array}$} & Ipoh campus & 109 & 26.3 \\
\hline & Bangi campus & 100 & 24.1 \\
\hline & Temenggong Ibrahim campus & 97 & 23.4 \\
\hline & Tengku Ampuan Afzan campus & 66 & 15.9 \\
\hline & Gaya campus & 43 & 10.4 \\
\hline \multirow[t]{2}{*}{ Gender } & Male & 96 & 23.1 \\
\hline & Female & 319 & 76.9 \\
\hline \multirow[t]{7}{*}{ Age } & 17 & 1 & .2 \\
\hline & 18 & 176 & 42.4 \\
\hline & 19 & 49 & 11.8 \\
\hline & 20 & 115 & 27.7 \\
\hline & 21 & 26 & 6.3 \\
\hline & 22 & 25 & 6.0 \\
\hline & 23 & 23 & 5.5 \\
\hline \multirow[t]{5}{*}{ Ethnicity } & Malay & 256 & 61.7 \\
\hline & Chinese & 114 & 27.5 \\
\hline & Indian & 22 & 5.3 \\
\hline & Malay Bumiputera & 21 & 5.1 \\
\hline & Natives & 2 & .5 \\
\hline \multirow[t]{3}{*}{ Program } & PPISMP & 212 & 51.1 \\
\hline & PISMP & 183 & 44.1 \\
\hline & PDPP & 20 & 4.8 \\
\hline \multirow{6}{*}{$\begin{array}{l}\text { Academic } \\
\text { year }\end{array}$} & 0 & 232 & 55.9 \\
\hline & 1 & 13 & 3.1 \\
\hline & 2 & 136 & 32.8 \\
\hline & 3 & 12 & 2.9 \\
\hline & 4 & 20 & 4.6 \\
\hline & 5 & 3 & .7 \\
\hline \multirow[t]{11}{*}{ Option } & Mathematics & 24 & 5.8 \\
\hline & Science & 55 & 13.3 \\
\hline & Islamic Studies & 97 & 23.4 \\
\hline & Malay Language & 102 & 24.6 \\
\hline & TESL & 55 & 13.3 \\
\hline & Chinese Language & 50 & 12.0 \\
\hline & Tamil Language & 3 & .7 \\
\hline & Music & 4 & 1.0 \\
\hline & Early Childhood Education & 12 & 2.9 \\
\hline & Counselling & 11 & 2.7 \\
\hline & History & 2 & .5 \\
\hline
\end{tabular}

\section{Analysis}

The result of the study demonstrated mean values within the range 3.65to 4.41 and the standard deviation ranging from 0.65 to 1.04 using the five-points Likert Scale. As illustrated in Table 5, the level of knowledge among the pre-service teachers in the 5 ITE in Malaysia is at high level according to a measurement scale that was established by Nunally (1997). However, their environmental sustainability behaviour is moderate high. This answers the first research question, which was "What is the level of knowledge of sustainability and environmental sustainability behaviour among the pre-service teachers in Malaysia. The high level of knowledge is due to the Sustainable ITE program, an adopted version of Eco-School program implemented to every Institutes of Teacher Education in Malaysia since 2012. This program, which were introduced by WWF, seek to instil environmental awareness, practice, knowledge and attitude into the trainings of future teachers as to produce teachers with environmental sustainability behaviour. This program has managed to develop positive behaviours towards the environment sustainability, through many in-campus programs yet is was not intended to add more burden in their daily schedule. 
Table 4. Descriptive analysis

\begin{tabular}{llll}
\hline Construct & Mean & $\begin{array}{l}\text { Standard } \\
\text { Deviation }\end{array}$ & Level \\
\hline Knowledge of Sustainability Action Skills (KAS) & 4.41 & 0.65 & High \\
Knowledge of Sustainability Strategies (KSS) & 4.41 & 0.63 & High \\
Knowledge of Sustainability Issues (KSI) & 4.05 & 0.80 & High \\
Behavioural Intention (IB) & 3.65 & \multicolumn{1}{c}{1.04} & Moderate high \\
Environmental Sustainability Behaviour & 3.94 & 0.83 & Moderate high \\
\hline
\end{tabular}

*According to the mean score interpretation by Nunnally (1997), 3.01-4.00 is considered as moderate high and 4.01-5.00 is considered as high.

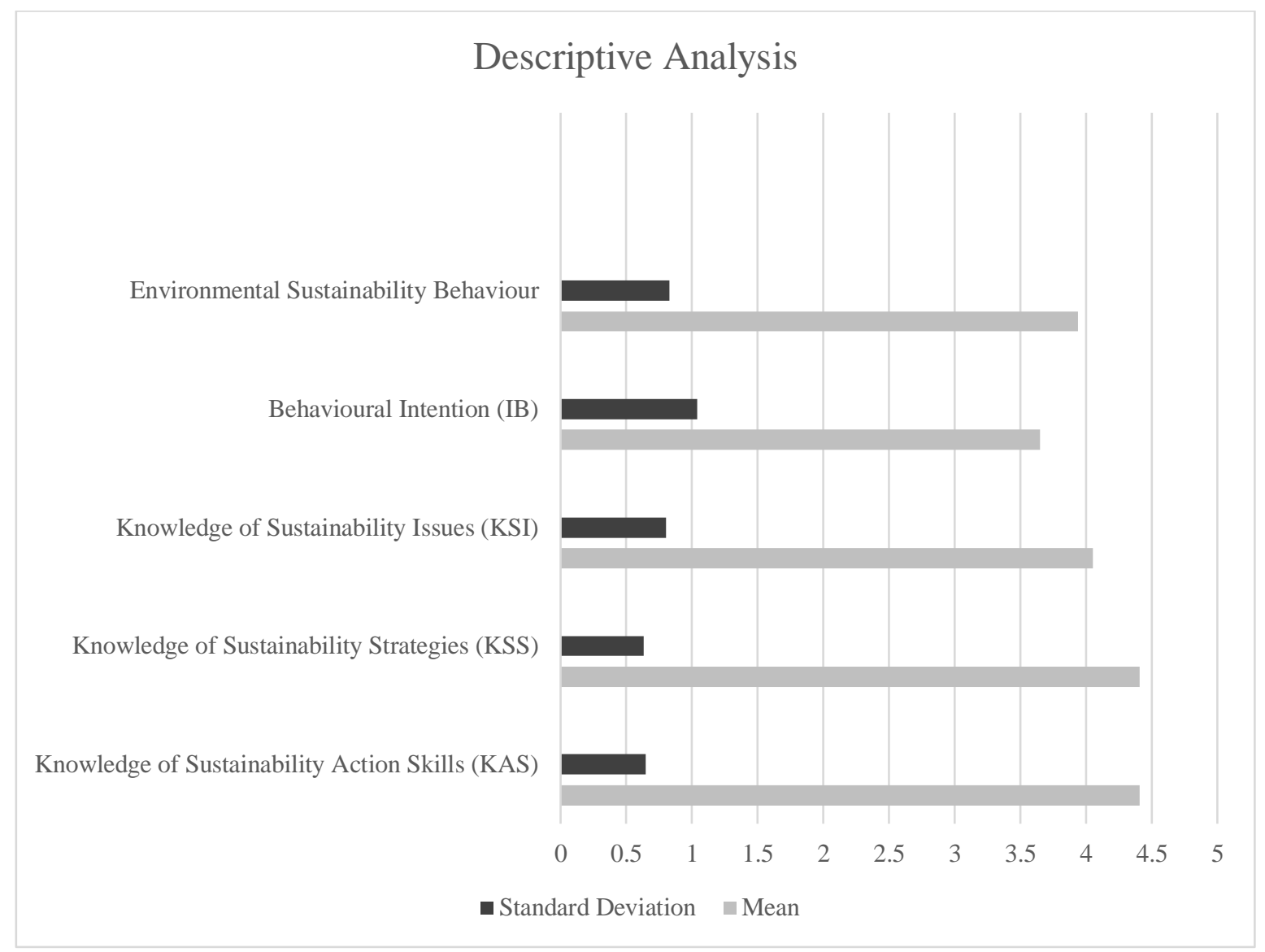

\section{Discussion}

These empirical findings are a great contribution in terms of its implications especially to the research theory, research method as well as organization. From theoretical point of view, the implications of this study is that student teachers needs to be exposed to knowledge on sustainability action skills, knowledge of sustainability strategies, knowledge for sustainability issues in order to trigger sustainable behavioural intention, thus producing environmentally sustainable behaviour among the future teachers of our children. (Hanifah, Shaharudin, Mohmadisa, Nasir, \& Yazid, 2015; Othman, Harun, Muda, \& Arif Ismail, 2013).

Higher educational institutions such as the Institutions of Teacher Education (ITE) are crucial in providing platforms to develop sustainable lifestyles if it includes ESD with transformative foundations(Pérez-Rodríguez, Varela-Losada, Álvarez-Lires, \& Vega-Marcote, 2017). Teachers have the ability to influence the children because their direct relationship with the learners. Furthermore, training of the future teachers are essential in this process, because of their responsibility in the process of teaching and learning and due to the fact that teachers' influence as role models towards the students (Pe_rez-Rodríguez et al, 2017). The research and engagement of educators in sustainable development and in utilizing innovative pedagogical approaches is therefore necessary. It should be acknowledged, though, that its use would take account of the complexity of the 
environmental system(Peters \& Wals, 2013). Nevertheless, more qualitative and quantitative analyses would be needed if the validity of the results were to be further improved and the measures psychometrical properties confirmed, the sum or number of items per variable described in the template. Such enhancements will need more work in this respect.

As to conclude this article, the factors discovered are the critical success factors that needs to be in the model for training preservice teachers in regards to implementing sustainability behaviour as to become teachers with proenvironmental behaviour when they embark on their journey as teachers in their career. Student teachers in the Higher Education Institutions as holders of interdisciplinary education, play one of the most vital role in this particular process. Besong \& Holland(2015)once revealed that "the purpose of integrating sustainability in higher education programmes is to enable the students to improve the quality of life on this planet while building fair, equitable and just futures for all. To effectively do this, the knowledge, skills and dispositions of higher education students need to be re-oriented towards sustainability".

\section{Conclusion}

In regards to the objectives that were set prior to the study, the authors can conclude that the critical success factors affecting environmentally sustainable behaviour among the student teachers are confirmed. Results of the research indicate the high critical success factors for knowledge on sustainability action skills, knowledge for sustainability strategies and knowledge of sustainability issues towards environmentally sustainable behaviour among the student teachers in the Institutes of Teacher Education.

This study also leads to an important conclusion in regards to sustainability education in teacher training settings. These future teachers are those who will be teaching our children and it is crucial that all of them have been exposed to sustainability education as to produce the future generation with literacy in environment and sustainability thus behaving with environmentally sustainable behaviour. Educational institutions contribute significantly towards developing sustainability lifestyles if it includes Environmental Education (EE) with transformative foundations. Integrating sustainability of education into the pre-service teachers training does not needto have drastic development of new programs or courses, although it can be the most successful.Sustainability education cannot add more content into the teachings because teacher trainees already have abundant of subjects and other skills they need to master at the same time. Student teachers need to have the ability to make the correct decision every time it involves the nature and the environment. That is the goal of sustainability teaching. Furthermore, teachers are vital in the process because they are directly responsible in the process of teaching and learning in school and also because of the influence as role models for the students.

\section{References}

1. Abd Rahman, N., \& Nasri, N. M. (2018). Environmental Literacy: Indigenizing Environmental Education. Creative Education, 9, 2148-2160. https://doi.org/10.4236/ce.2018.914156

2. Ajzen, I. (1985). Behavioral Interventions Based on the Theory of Planned Behavior. Action Control, 1139. https://doi.org/10.1007/978-3-642-69746-3_2

3. Al-Naqbi, A. K., \& Alshannag, Q. (2018). The status of education for sustainable development and sustainability knowledge, attitudes, and behaviors of UAE University students. International Journal of Sustainability in Higher Education, 19(3), 566-588. https://doi.org/10.1108/IJSHE-06-2017-0091

4. Alim M. (2014). The Knowledge and Attitudes of Primary School Teaching Students Towards Environment. Eastern Geographical Review, 31, 23-36.

5. Bartlett II, J. E., Kotrlik, J. W., \& Higgins, C. C. (2001). Determing appropriate sample size in survey research. Information Technology, Learning, and Performance Journal, 19(1), 43-50.

6. Besong, F., \& Holland, C. (2015). The Dispositions, Abilities and Behaviours (Dab) Framework for Profiling Learners' Sustainability Competencies in Higher Education. Journal of Teacher Education for Sustainability, 17(1), 5-22. https://doi.org/10.1515/jtes-2015-0001

7. Birdsall, S. (2014). Measuring student teachers' understandings and self-awareness of sustainability. Environmental Education Research, 20(6), 814-835. https://doi.org/10.1080/13504622.2013.833594

8. Clayton, S., \& Myers, G. (2009). Conservation psychology: understanding and promoting human care for nature. In Wiley Blackwell (2ND ed.). https://doi.org/10.1017/S0376892910000457

9. Filho, W. L., Skanavis, C., Do Paço, A., Rogers, J., Kuznetsova, O., \& Castro Editors, P. (2017). World Sustainability Series Handbook of Theory and Practice of Sustainable Development in Higher Education (Vol. 2).

10. Gericke, N., Boeve-de Pauw, J., Berglund, T., \& Olsson, D. (2018). The Sustainability Consciousness Questionnaire: The theoretical development and empirical validation of an evaluation instrument for stakeholders working with sustainable development. Sustainable Development, (October 2017), 1-15. https://doi.org/10.1002/sd.1859

11. Hair, J. F., Ringle, C. M., Sarstedt, M., Hair, J. F., Ringle, C. M., \& Sarstedt, M. (2015). PLS-SEM : 
Indeed a Silver Bullet PLS-SEM: Indeed a Silver Bullet. 6679(December). https://doi.org/10.2753/MTP1069-6679190202

12. Hanifah, M., Shaharudin, I., Mohmadisa, H., Nasir, N., \& Yazid, S. (2015). Transforming Sustainability Development Education in Malaysian Schools through Greening Activities. Review of International Geographical Education Online @RIGEO, 5(1), 78-94.

13. Hines, J. M., Hungerford, H. R., \& Tomera, A. N. (1987). Analysis and synthesis of research on responsible environmental behavior: A meta-analysis. Journal of Environmental Education, 18(2), 1-8. https://doi.org/10.1080/00958964.1987.9943482

14. Ho, Y., Kamaruddin, M. K. I., \& Ismail, A. (2016). Integration of sustainable consumption education in the Malaysian School Curriculum : Opportunities and barriers. SHS Web of Conferences 26, 01061.

15. Kaiser, F.G., Woelfing, S. \& Fuhrer, U. (1999). ENVIRONMENTAL ATTITUDE AND ECOLOGICAL BEHAVIOUR FLORIAN. Journal of Environmental Psychology, 19, 1-19.

16. Kalsoom, Q., \& Khanam, A. (2017). Inquiry into sustainability issues by preservice teachers: A pedagogy to enhance sustainability consciousness. Journal of Cleaner Production, 164, 1301-1311. https://doi.org/10.1016/j.jclepro.2017.07.047

17. Kidman, G., Chang, C-H., \& Wi, A. (2018). Defining education for sustainability (EfS): A Theoretical Framework. In Issues of Teaching and Learning of Education for Sustainability (1ST ed., pp. 1-13). https://doi.org/https://doi.org/10.4324/9780429450433-1

18. Kollmuss, A., \& Agyeman, J. (2002). Mind the Gap: Why Do People Behave Environmentally and What are the Barriers to Pro-Environmental Behaviour. Environmental Education Research, 8(3), 239-260. https://doi.org/10.1080/1350462022014540

19. Mahat, H., \& Idrus, S. (2016). Education for sustainable development in Malaysia: A study of teacher and student awareness. Malaysian Journal of Society and Space, 12(6), 77-88.

20. Nguyen, T. P. (2018). Education for Sustainable Development in Vietnam: exploring the geography teachers' perspectives. International Research in Geographical and Environmental Education, 27(4), 341-356. https://doi.org/10.1080/10382046.2017.1366204

21. Othman, R., Harun, R., Muda, A., \& Arif Ismail, I. (2013). KESAN PENGAJARAN DAN PEMBELAJARAN PENDIDIKAN ALAM SEKITAR MELALUI AKTIVITI MELUKIS MURAL UNTUK MENINGKATKAN PENGETAHUAN DAN KESEDARAN PELAJAR SEKOLAH MENENGAH TERHADAP ALAM SEKITAR (THE EFFECT OF TEACHING AND LEARNING OF ENVIRONMENTAL EDUCATION THROUGH MURAL PAINTING ACTIVITY IN ENHANCING THE KNOWLEDGE AND AWARENESS OF SECONDARY SCHOOL STUDENTS TOWARDS THE ENVIRONMENT). Asia Pacific Journal of Educators and Education, 28, 11-31.

22. Owens, K. A., \& Legere, S. (2015). What do we say when we talk about sustainability? Analyzing faculty, staff and student definitions of sustainability at one american university. International Journal of Sustainability in Higher Education, 16(3), 367-384. https://doi.org/10.1108/IJSHE-06-2013-0055

23. Pérez-Rodríguez, U., Varela-Losada, M., Álvarez-Lires, F. J., \& Vega-Marcote, P. (2017). Attitudes of preservice teachers: Design and validation of an attitude scale toward environmental education. Journal of Cleaner Production, 164, 634-641. https://doi.org/10.1016/j.jclepro.2017.06.245

24. Peters, S. J., \& Wals, A. E. J. (2013). Learning and Knowing in Pursuit of Sustainability: Concepts and Tools for Transdisciplinary Environmental Research. Trading Zones in Environmental Education: Creating Transdisciplinary Dialogue, (January 2013), 79-104.

25. Scoullos, M., Malotidi, V., Lindroos, P., \& Suomalainen, S. (2017). Learning for and about sustainability in higher education - a regional perspective based on experiences from the Baltic and the Mediterranean. International Journal of Sustainability in Higher Education, 18(6), 877-893. https://doi.org/10.1108/IJSHE-03-2016-0056

26. Singer-Brodowski, M. (2017). Pedagogical content knowledge of sustainability: A missing piece in the puzzle of professional development of educators in higher education for sustainable development. International Journal of Sustainability in Higher Education, 18(6), 841-856. https://doi.org/10.1108/IJSHE-02-2016-0035

27. Torres, R., Vieira, R. M., Rodrigues, A. V., Sá, P., \& Moreira, G. (2017). Education for sustainable development: an exploratory study in a Portuguese University. International Journal of Sustainability in Higher Education, 18(6), 956-970. https://doi.org/10.1108/IJSHE-05-2016-0082

28. UNESCO, Buckler, C., \& Creech, H. (2014). Shaping the Future We Want. In United Nations Educational, Scientific and Cultural Organization. https://doi.org/10.5363/tits.11.4_46

29. Zikmund, W. G. (2012). Business Research Methods.(7Th ed.). USA: Cengage Learning. 